\title{
ANALISIS LAPORAN KEUANGAN PADA PALACE HOTEL CIPANAS (Studi pada PT Catur Situ Pratama)
}

\author{
Isna Salamah ${ }^{1}$ Iqbal Ramadhan ${ }^{2}$ Jihan Hasna al-Hakim $^{3}$ Lisdawati $^{4}$ Lita $^{7}$ \\ Damayanti $^{5}$ Lukman Nulhakim $^{6}$ Lutvi Amalia $^{7}$ \\ 1,2,3,4,5,6,7 Universitas Islam Negeri Sunan Gunung Djati \\ Email:info@uinsgd.ac.id
}

\begin{abstract}
Abstrak
Tujuan dari penelitian ini adalah untuk menunjukkan kinerja keuangan perusahaan yang diukur melalui analisis rasio keuangan, terdiri dari : rasio profitabilitas (Net Profit Margin, Return of Investment, Return on Equity), rasio likuiditas (Current Ratio, Quick Ratio, Cash Ratio), rasio aktivitas (Inventory Turn Over, Fixed Asset Turn Over, Total Asset Turn Over), dan rasio solvabilitas (Total Debt to Total Asset, Total Debt to Equity Ratio). Objek penelitian ini adalah Palace Hotel Cipanas. Jenis Penelitian yang dilakukan adalah penelitian kuantitatif dengan menggunakan studi deskriptif. Fokus penelitian adalah laporan keuangan perusahaan yang terdiri dari neraca, laporan laba-rugi dan laporan audit periode tahun 2016-2018. Sumber data yang digunakan adalah data sekunder. Metode pengumpulan data yang digunakan dalam penelitian ini adalah dokumentasi dan studi pustaka. Analisis data yang digunakan dalam penelitian ini adalah analisis deskriptif dengan menggunakan analisis rasio keuangan. Hasil analisis rasio keuangan yang terdiri dari rasio profitabilitas, rasio likuiditas, rasio aktivitas, dan rasio solvabilitas periode 2016- 2018 menunjukkan bahwa Palace Hotel dikatakan belum cukup stabil dalam proses perputarannya, karena sering kali mengalami penurunan dan peningkatan yang berbeda di setiap tahunya. Namun demikian, Palace Hotel mencatatkan kinerja keuangan yang saling menutupi kekurangan yang membuat Palace Hotel tetap berjalan dengan baik.
\end{abstract}

Kata kunci : Rasio Keuangan, Kinerja Keuangan

\begin{abstract}
Abstrack
The purpose of this study was to show the financial performance in terms of finansial ratios analysis which is: profitability ratios (Net Profit Margin, Return of Investment, Return on Equity), liquidity ratios (Current Ratio, Quick Ratio, Cash Ratio), activity ratios (Inventory Turn Over, Fixed Asset Turn Over, Total Asset Turn Over), and leverage ratios (Total Debt to Total Asset, Total Debt to Equity Ratio). The object of this study is Palace Hotel Cipanas. This type of research is quantitative descriptive study. The focus of this research is the company's financial statements: balance sheets, the profit and losses and balance sheet audit of the period 2016-2018. Sources of data used in the study are secondary data and literature study. Data collection techniques used in this study is documentations. The analysis of data used in this study is descriptive analysis. The results of financial ratios analysis which is profitability ratios, liquidity ratios, activity ratios, and leverage ratios in periode 2016-2018 show that Palace Hotel is not stable enough in its turnaround process, which often experiences a different decrease and increase every year. Nevertheless, Palace Hotel recorded its financial performance cover each other's shortcomings that keeps Palace Hotel running well.
\end{abstract}

Keywords: Financial Ratios, Financial Performances 


\section{A. PENDAHULUAN}

Sebagai pelaku dalam industri pariwisata Palace Hotel Cipanas sangat bergantung pada pengunjung yang datang untuk mendapatkan layanan dari Palace Hotel, seperti kunjungan dari wisatawan domestik maupun wisatawan asing yang menginap dan mendapatkan layanan lainya dari Palace Hotel, juga ada pengunjung yang menyewa ruangan atau layanan meeting dari Palace Hotel untuk melakukan pertemuanpertemuan organisasi bisnis, baik bisnis profit maupun non profit, oleh karena itu dalam menganalisis kinerja keuangan manajemen hotel kami mengumpulkan data terkait dengan kinerja keuangan hotel yang berasal dari laporan keuangan.

Laporan keuangan merupakan hasil akhir dari proses akuntansi pada satu waktu periode tertentu ( biasanya satu tahun), yang merupakan hasil pengumpulan dan pengolahan data keuangan yang disajikan dalam bentuk laporan keuangan sederhana atau ikhtisar lainya yang dapat digunakan untuk membantu para pemakainya dalam mengambil keputusan, nama perusahaan dari Palace Hotel ini adalah PT. Catur Situ Pratama, walaupun bukan perusahaan induk dan juga bukan perusahaan Tbk yang menerbitkan saham dan membuka peluang bagi investor untuk memiliki perusahaan, akan tetapi tetap saja Palace Hotel ini tetap harus mengukur kinerja keuangannya sehingga para pemilik perusahaan bisa mengambil keputusan agar manajemen hotel semakin baik dan kinerja keuangan juga semakin baik, selain itu hotel yang sudah berdiri sejak 1991 ini bisa meningkatkan kualitas layanannya dengan melihat kinerja keuangan sehingga konsumen akan lebih merasakan mutu atau kepuasan dari layanan hotel yang tentu akan berdampak positif bagi keuntungan perusahaan

Untuk mengukur kinerja keuangan hotel ini digunakan rasio-rasio keuangan yaitu Rasio Profitabilitas, adalah rasio atau perbandingan untuk mengetahui kemampuan perusahaan untuk mendapatkan laba (profit) dari pendapatan (earning) terkait penjualan, aset, dan ekuitas berdasarkan dasar pengukuran tertentu, kemudian Rasio Likuiditas ( kemampuan perusahaan memenuhi kewajiban lancarnya ), Rasio Solvabilitas (kemampuan perusahaan memenuhi seluruh kewajibannya), dan Rasio Aktivitas, Rasio yang mengukur seberapa efektif perusahaan dalam memanfaatkan semua sumber daya yang ada padanya. Rasio- rasio tersebut untuk mengukur apakah perusahaan mengalami peningkatan kinerja atau justru mengalami penurunan dari satu periode ke periode berikutnya

\section{B. Rumusan Masalah}


Berdasarkan latar belakang di atas maka rumusan masalah penelitian dalam jurnal ini yaitu : Apakah Palace Hotel Cipanas ini mencatatkan kinerja keuangan yang baik dari tahun ke tahun diukur dengan menggunakan rasio profitabilitas, likuiditas, solvabilitas, dan aktivitas?

\section{Tujuan Penelitian}

Adapun tujuan yang ingin dicapai dari penelitian ini adalah untuk mengetahui kinerja keuangan dari Palace Hotel Cipanas, apakah menunjukkan prestasi yang baik atau tidak dan sekaligus juga mengetahui kondisi kesehatan keuangan dari Palace Hotel yang akan berdampak pada jalanya bisnis Palace Hotel.

\section{KAJIAN PUSTAKA}

\section{Pengertian Laporan Keuangan}

Menurut Ikatan Akuntansi Indonesia (2009:1) "Laporan keuangan meliputi bagian dari proses pelaporan keuangan. Laporan keuangan yang lengkap meliputi neraca, laporan laba rugi, laporan ekuitas, laporan posisi keuangan (yang dapat disajikan dalam berbagai cara misalnya, sebagai laporan arus kas/laporan arus dana), catatan dan laporan lain serta materi penjelasan yang merupakan bagian integral dari laporan keuangan”.

Menurut Munawir (2010:5) "Pada umumnya laporan keuangan itu terdiri dari neraca dan perhitungan laba-rugi serta laporan perubahan ekuitas. Neraca menunjukkan/menggambarkan jumlah asset, kewajiban dan ekuitas dari suatu perusahaan pada tanggal tertentu.

Jadi, laporan keuangan merupakan kewajiban setiap perusahaan untuk membuat, menyajikan, dan melaporkan kondisi keuangan perusahaannya pada suatu periode tertentu. Laporan keuangan juga dapat dijadikan sebagai bahan pertimbangan untuk mengambil keputusan oleh pihak manajemen perusahaan di masa sekarang dan yang akan datang.

\section{Tujuan Analisis Laporan Keuangan}

Menurut Prastowo dan Yulianti (2005:57), tujuan analisis laporan keuangan mencakup empat hal yaitu :

a. Sebagai alat screening adalah awal dalam memilih alternatif investasi atau 
merger.

b. Sebagai alat forecasting adalah mengenai kondisi dan kinerja keuangan di masa datang.

c. Sebagai proses diagnosis terhadap masalah-masalah manajemen operasi atau masalah lainnya.

Menurut Kasmir (2014) tujuan analisis laporan keuangan ada enam, yaitu:

1. Untuk mengetahui posisi keuangan perusahaan dalam satu periode tertentu, baik aset, kewajiban, ekuitas, maupun hasil usaha yang telah dicapai untuk beberapa periode.

2. Untuk mengetahui kelemahan-kelemahan apa saja yang menjadi kekurangan perusahaan.

3. Untuk mengetahui kekuatan-kekuatan yang dimiliki.

4. Untuk mengetahui langkah-langkah perbaikan apa saja yang perlu dilakukan ke depan berkaitan dengan posisi keuangan perusahaan saat ini.

5. Untuk melakukan penilaian kinerja manajemen ke depan apakah perlu penyegaran atau tidak karena sudah dianggap berhasil atau gagal.

6. Dapat juga digunakan sebagai pembanding dengan perusahaan sejenis tentang hasil yang mereka capai.

\section{Manfaat Analisis Laporan Keuangan}

Menurut Sugiono dan Untung (2016:10) kegunaan analisis laporan keuangan adalah:

1. Untuk memberikan informasi yang lebih mendalam terhadap laporan keuangan itu sendiri

2. Untuk mengungkapkan hal-hal yang bersifat tidak konsisten dalam hubungannya dengan suatu laporan keuangan

3. Dapat memberikan informasi yang diinginkan oleh para pengambil keputusan

4. Dapat digunakan untuk membandingkan dengan perusahaan lain

5. Untuk memahami situasi dan kondisi keuangan perusahaan

6. Dapat juga digunakan untuk memprediksi bagaimana keadaan perusahaan pada masa mendatang (proyeksi)

\section{Metode dan Teknik Analisis Laporan Keuangan}

a. Metode Analisis Laporan Keuangan 
Metode yang digunakan untuk analisis laporan keuangan menurut Munawir (1995:36) dibedakan sebagai berikut :

1) Analisis Horizontal (Dinamis) adalah analisis dengan mengadakan perbandingan laporan keuangan dari beberapa periode sehingga akan diketahui perkembangannya.

2) Analisis Vertikal (Statis) adalah analisis yang membandingkan pos yang satu dengan pos yang lainnya dalam laporan keuangan. Dan laporan keuangan yang di analisis tersebut hanya meliputi satu periode atau satu saat saja, sehingga hanya akan diketahui keadaan keuangan atau hasil operasi pada saat itu.

b. Teknik Analisis Laporan Keuangan

Beberapa teknik analisis laporan keuangan menurut Munawir (2002:36) sebagai berikut :

1) Analisis perbandingan laporan keuangan

2) Analisis trend atau tendensi posisi dan kemajuan keuangan perusahaan yang dinyatakan dalam persentase (Trend Percentage Analysis)

3) Analisis laporan dengan persentase per komponen (Common Size Statement)

4) Analisis sumber penggunaan modal kerja

5) Analisis sumber dan penggunaan kas (Cash Flow Statement)

6) Analisis rasio

7) Analisis perubahan laporan keuangan (Gross Profit Analysis)

8) Analisis Break Event

\section{Rasio Keuangan}

\section{Analisis Rasio Keuangan}

Analisis rasio menurut pendapat Warsidi dan Bambang dalam Fahmi (2011) "Instrumen analisis prestasi dari perusahaan yang menjelaskan berbagai hubungan dan indicator keuangan yang ditujukan untuk menunjukan perubahan dalam kondisi keuangan atau prestasi operasi di masa lalu dan membantu menggambarkan trend pola perubahan tersebut, untuk kemudian menunjukkan risiko dan peluang yang melekat pada perusahaan yang bersangkutan." Pendapat lain oleh Irham Fahmi (2012:107) menyatakan, bahwa analisis rasio ini sangat penting gunanya untuk melakukan analisis 
terhadap kondisi keuangan perusahaan. Bagi investor jangka pendek dan menengah pada umumnya lebih banyak tertarik kepada kondisi keuangan jangka pendek dan kemampuan perusahaan untuk membayar dividen yang memadai. Informasi tersebut dapat diketahui dengan cara lebih sederhana yaitu dengan menghitung rasio-rasio keuangan yang sesuai dengan keinginan.

Berdasarkan pendapat di atas, dapat disimpulkan bahwa rasio keuangan merupakan metode perhitungan dan interpretasi rasio keuangan untuk menilai kinerja dan status keungan dalam suatu perusahaan.

\section{Jenis-jenis Analisis Rasio Keuangan}

\section{a. Rasio Profitabilitas}

Menurut Kasmir (2014:115), "Rasio Profitabilitas merupakan rasio untuk menilai kemampuan perusahaan dalam mencari keuntungan. Rasio ini juga memberikan ukuran tingkat efektivitas manajemen suatu perusahaan. Hal ini ditunjukkan oleh laba yang dihasilkan dari penjualan dan pendapatan investasi."

1) Return On Equity (ROE)

Hasil pengebalian ekuitas atau Return On Equity (ROE) atau rentabilitas modal sendiri modal sendiri, merupakan rasio untuk mengukur laba bersih sesudah pajak dengan modal sendiri. Rasio ini menunjukkan efisiensi penggunaan modal sendiri. Makin tinggi rasio ini, makin baik. Artinya, posisi pemilik perusahaan makin kuat, demikian pula sebaliknya. Rumusnya sebagai berikut :

$$
R O E=\frac{\text { Laba Setelah Pajak }}{\text { Modal Sendiri }}
$$

(Kasmir, 2014:137)

\section{2) Return On Assets (ROA)}

Hasil pengembalian Investasi atau lebih dikenal dengan nama Return on Investment ROI atau Return on Total Assets, merupakan rasio yang menunjukkan hasil (return) atas jumlah aktiva yang digunakan dalam perusahaan. ROI juga merupakan suatu ukuran tentang efektifitas manajemen dalam mengelola investasinya. Rumusnya sebagai berikut : 


\section{Laba Setelah Pajak$$
R O A=
$$ \\ Total Aktiva}

(Kasmir, 2014:136)

\section{3) Net Profit Margin}

Menunjukkan kemampuan perusahaan untuk menghasilkan laba pada tingkat penjualan tertentu. Secara umum rasio rendah menunjukkan ketidakefisienan manajemen. Rumusnya sebagai berikut :

\section{Laba Setelah Pajak}

\section{Net Profit Margin $=\longrightarrow \times 100 \%$ Penjualan}

(Sartono, 2011:114)

\section{b. Rasio Likuiditas}

Menurut Subramanyam (2010:10) "Rasio Likuiditas merupakan kemampuan perusahaan untuk menghasilkan kas dalam jangka pendek untuk memenuhi kewajibannya dan bergantung pada arus kas perusahaan serta komponen asset dan kewajiban lancarnya." Berikut jenis-jenis rasio likuiditas yang dikemukakan oleh Kasmir (2014:119) :

1) Current Ratio

Rasio untuk mengukur kemampuan perusahaan membayar kewajiban jangka pendek atau utang yang segera jatuh tempo pada saat ditagih secara keseluruhan. Dengan kata lain, seberapa banyak aktiva lancer yang tersedia untuk menutupi kewajiban jangka pendek yang segera jatuh tempo. Current Ratio (Rasio Lancar) dapat pula dikatakan sebagai bentuk untuk mengukur tingkat keamanan suatu perusahaan. Rumusnya sebagai berikut :

$$
\text { Current Ratio }=\frac{\text { Aktiva Lancar }}{\text { Utang Lancar }}
$$

(Sartono, 2011:114)

2) Rasio Cepat (Quick Ratio)

Rasio yang menunjukkan kemampuan perusahaan memenuhi atau 
membayar kewajiban atau utang lancer (utang jangka pendek) dengan aktiva lancar tanpa memperhitungkan nilai sediaan (inventory). Rumusnya sebagai berikut :

$$
\text { Quick Ratio }=\frac{\text { Aktiva Lancar }- \text { Persediaan }}{\text { Utang Lancar }}
$$

(Sartono, 2011:114)

\section{3) Kas Rasio (Cash Ratio)}

Rasio yang digunakan untuk mengukur seberapa besar uas kas yang tersedia untuk membayar utang. Ketersediaan uang kas dapat ditunjukkan dari tersedianya dana kas atau yang setara dengan kas seperti rekening giro atau tabungan yang ada di bank. Rasio ini menunjukkan kemampuan sesungguhnya bagi perusahaan untuk membayar utang-utang jangka pendek. Rumusnya sebagai berikut :

$$
\text { Cash Ratio }=\frac{\text { Kas }+ \text { Setara Kas }}{\text { Utang Lancar }} \times 100 \%
$$

(Munawir, 2001:76)

\section{c. Rasio Solvabilitas}

Menurut Kasmir (2008:151) “ rasio yang digunakan untuk mengukur sejauh mana aktiva perusahaan dibiayai dengan hutang. Artinya berapa besar beban utang yang ditanggung perusahaan dibandingkan dengan aktivanya. Dalam arti luas dikatakan bahwa rasio solvabilitas digunakan untuk mengukur kemampuan perusahaan untuk membayar seluruh kewajibannya, baik jangka pendek maupun jangka panjang apabila perusahaan dibubarkan.

1) Debt to equity ratio (DER)

Rasio ini digunakan untuk mengetahui perbandingan antara total hutang dengan modal sendiri. Rumus untuk mencari rasio ini yaitu :

Total Utang

$$
\mathrm{DER}=\longrightarrow \times 100 \%
$$

Ekuitas 
2) Debt to asset Ratio (DAR)

Rasio hutang yang digunakan untuk mengukur perbandingan total utang dengan total aktiva. Rumus untuk mencari rasio ini yaitu :

$$
D A R=\frac{\text { Total Utang }}{\text { Total Aktiva }} \times 100 \%
$$

(Sawir, 2005:13)

\section{d. Rasio Aktivitas}

Menurut Harahap (2002:240), "Rasio aktivitas adalah rasio yang menggambarkan aktivitas yang dilakukan perusahaan dalam menjalankan operasinya baik dalam kegiatan penjualan, pembelian, dan kegiatan lainnya.”

1) Inventory Turnover

Rasio yangmenunjukkan berapa kali jumlah barang sediaan diganti dalam 1 tahun. Semakin kecil rasio ini semakin jelek, demikian pula sebaliknya. Turunan dari perputaran sediaan adalah jumlah hari untuk menjual sediaan.Rumus untuk mencari Inventory Turnover yaitu :

$$
\text { Inventory Turnover }=\frac{\text { Penjualan }}{\text { Persediaan }}
$$

(Sartono, 2011:114)

\section{2) Fixed Asset Turnover}

Rasio yang digunakan untuk mengukur apakah perusahaan sudah sepenuhnya atau belum menggunakan kapasitas aktiva tetap yang dimiliki perusahaan serta berapa kali dana yang diinvestasikan dalam aktiva tetap berputar dalam satu periode.

$$
\text { Fixed Asset Turnover }=\frac{\text { Penjualan }}{\text { Total Aktiva Tetap }}
$$

(Kasmir, 2014)

\section{3) Total Asset Turnover}

Rasio ini menunjukkan perputaran total aktiva yang diukur dari volume penjualan. Maka dengan kata lain mengukur seberapa jauh kemampuan semua 
aktiva menciptakan penjualan. Rumus Total Asset Turnover :

$$
\text { Total Asset Turnover }=\frac{\text { Penjualan Bersih }}{\text { Total Aset }}
$$

(Harahap, 2009:309)

4) Average Collection Period

Ratarata yang diperlukan untuk mengubah piutang menjadi kas. Biasanya ditentukan dengan membagi piutang dengan rata-rata penjualan harian. Rumus Average Collection Period :

$$
\text { Average Collection Period }=\frac{\text { Rata }- \text { rata Piutang Usaha }}{\text { Penjualan Bersih }} \times 360 \text { hari }
$$

(Sartono, 2011:114)

5) Receivable Turnover

Salah satu rasio aktivitas yang menggambarkan berapa kali persediaan dapat diubah menjadi kas selama satu periode.

$$
\text { Recevable Turnover }=\frac{\text { Penjualan Bersih }}{\text { Rata }- \text { rata Piutang Usaha }}
$$

(Horne dalam kasmir, 2014)

6) Working Capital Turn Over

Rasio yang digunakan untuk mengukur berapa kali dana yang ditanamkan dalam modal kerja berputar dalam satu periode atau berapa penjualan yang dapat dicapai oleh setiap modal kerja yang diinginkan.

$$
\text { Working Capital Turnover }=\frac{\text { Penjualan neto }}{\text { Aktiva lancar }- \text { Kewajiban lancar }}
$$

(Kasmir, 2014)

\section{E. METODE PENELITIAN}

\section{Lokasi Penelitian}

Penelitian ini dilakukan pada Hotel Palace yang beralamat di Jalan Raya Cipanas, Km 81,2, Kecamatan Cipanas, Kabupaten Cianjur.

\section{Jenis Penelitian}


Penelitian ini menggunakan jenis penelitian kuantitatif dengan menggunakan studi deskriptif, yaitu sebuah penelitian yang merumuskan dan menafsirkan data yang tersedia sehingga dapat memberikan uraian yang jelas terkait objek yang diteliti.

\section{Metode pengumpulan data}

Teknik pengumpulan data dalam penelitian ini bertujuan untuk mendapatkan data yang relevan serta akurat dengan masalah yang dibahas. Adapun metode pengumpulan data yang dilakukan adalah sebagai berikut:

a. Studi Pustaka

Studi pustaka merupakan teknik pengumpulan data dengan cara mempelajari literatur dan lain sebagainya yang berhubungan dengan penelitian ini.

b. Dokumentasi

Dokumentasi adalah teknik pengumpulan data dengan menggunakan dokumendokumen atau catatan tertulis yang didapat di perusahaan yang berkaitan dengan laporan keuangan.

\section{Metode Analisis Data}

Penelitian ini menggunakan metode analisis kuantitatif. Analisis kuantitatif adalah analisis data yang dilakukan dengan cara melakukan perbandingan terhadap hasil analisis rasio keuangan untuk periode yang akan diteliti. Analisis keuangan yang digunakan dalam penelitian ini adalah rasio profitabilitas, rasio likuiditas, rasio solvabilitas, dan rasio aktivitas.

\section{F. HASIL PENELITIAN}

\section{Rasio Profitabilitas}

\section{Return On Equity (ROE)}

Return on Equity Palace Hotel pada tahun 2016:

$$
R O E=\frac{-5.680 .600 .496}{-9.923 .188 .558} \times 100 \%=57,24 \%
$$


Return on Equity Palace Hotel pada tahun 2017:

$$
R O E=\frac{-8.737 .346 .977}{-18.085 .025 .044} \times 100 \%=48,31 \%
$$

Return on Equity Palace Hotel pada tahun 2018:

$$
R O E=\frac{-7.359 .019 .358}{-24.650 .953 .111} \times 100 \%=29,85 \%
$$

Hasil perhitungan Return On Equity (ROE) dari tahun 2016 sampai tahun 2018 menunjukkan adanya penurunan dari tahun ke tahun yaitu pada tahun 2016 sebesar 57,24\%, tahun 2017 sebesar 48,31\%, dan tahun 2018 sebesar 29,85\%. Hal ini terjadi karena laba bersih mengalami penurunan dan jumlah ekuitas meningkat. Berdasarkan data-data tersebut maka terdapat dua kesimpulan dalam analisis ini yaitu pertama, perusahaan belum mampu memaksimalkan modal untuk mencetak keuntungan yang besar. Kedua, perusahaan belum bisa memuaskan kepentingan pemegang saham.

\section{Return On Asset (ROA)}

Return on Asset Palace Hotel pada tahun 2016:

$$
R O A=\frac{-5.680 .600 .496}{43.401 .961 .444} \times 100 \%=-13,08 \%
$$

Return on Asset Palace Hotel pada tahun 2017:

$$
R O A=\frac{-8.737 .346 .977}{36.714 .292 .554} \times 100 \%=-23,80 \%
$$

Return on Asset Palace Hotel pada tahun 2018:

$$
R O A=\frac{-7.359 .019 .558}{31.350 .143 .527} \times 100 \%=-23,47 \%
$$

Hasil perhitungan Return On Aset (ROA) dari tahun 2016 sampai tahun 2018 menunjukkan adanya kondisi turun naik, yaitu pada tahun 2016 sebesar $-13,08 \%$, tahun 2017 sebesar $-23,80 \%$, dan tahun 2018 sebesar $-23,47 \%$. Penyebab penurunan ROA pada tahun 2017 disebabkan oleh laba bersih dan aset total yang menurun. Kemudian, pada tahun 2018 terjadi kenaikan ROA dikarenakan laba bersih mengalami kenaikan dan aset total menurun. Berdasarkan data-data tersebut maka terdapat dua kesimpulan dalam analisis ini. 
Pertama, pada tahun 2017 ROA turun memiliki makna bahwa perusahaan belum bisa memaksimalkan aset total yang dimilikinya menjadi laba bersih. Kedua, pada tahun 2018 perusahaan telah menggunakan aset yang dimilikinya dengan lebih baik dari tahun sebelumnya sehingga ROA mengalami kenaikan sebesar 0,33\%. Akan tetapi, meskipun terdapat kenaikan pada $R O A$ di tahun 2018, kondisi perusahaan ini masih sedang tidak sehat, karena secara keseluruhan nilai $R O A$ masih menyentuh bilangan negatif.

\section{Net Profit Margin}

Net Profit Margin Palace Hotel Tahun 2016 :

$$
N P M=\frac{-5.680 .600 .496}{25.753 .889 .113} \times 100 \%=-22,057 \%
$$

Net Profit Margin Palace Hotel Tahun 2017 :

$$
N P M=\frac{-8.737 .346 .977}{22.278 .027 .495} \times 100 \%=-39,219 \%
$$

Net Profit Margin Palace Hotel Tahun 2018 :

$$
N P M=\frac{-7.359 .019 .358}{20.671 .581 .898} \times 100 \%=-35,59 \%
$$

Hasil perhitungan Net Profit Margin diatas menunjukkan kemampuan perusahaan dalam menghasilkan keuntungan kurang baik. Karena ukuran NPM yang baik, jika angka yang dihasilkan lebih besar dari $5 \%$.

\section{Rasio Likuiditas}

\section{Current Ratio}

Current Ratio Palace Hotel Tahun 2016 :

$$
\text { Current Ratio }=\frac{2.522 \cdot 435 \cdot 245}{7 \cdot 384 \cdot 000 \cdot 000}=0,34
$$

Current Ratio Palace Hotel Tahun 2017 :

$$
\text { Current Ratio }=\frac{1.810 \cdot 893.892}{10.818 .487 .955}=0,16
$$

Current Ratio Palace Hotel Tahun 2018 : 


\section{Current Ratio $=\frac{}{13.846 .142 .221}=0,21$}

Hasil perhitungan Current Ratio dari tahun 2016 sampai dengan tahun 2018 menunjukkan adanya kondisi turun dan naik, yaitu pada tahun 2016 sebesar 0,34 kali, tahun 2017 sebesar 0,16 kali, dan tahun 2018 sebesar 0,21 kali. Karena nilainya berada dibawah rata-rata industri yaitu di atas 2 kali, maka Current Ratio Palace Hotel dalam keadaan tidak likuid. Penyebab dari tidak likuid yaitu dari hutang usaha yang cukup tinggi dari 3 tahun tersebut.

\section{Quick Ratio}

Quick Ratio Palace Hotel Tahun 2016 :

$$
\text { Quick Ratio }=\frac{2.522 .435 .245-1.092 .006 .117}{7.384 .000 .000} \times 100 \%=19 \%
$$

Quick Ratio Palace Hotel Tahun 2017 :

$$
\text { Quick Ratio }=\frac{1.810 .893 .892-539.369 .845}{10.818 .487 .955} \times 100 \%=12 \%
$$

Quick Ratio Palace Hotel Tahun 2018 :

$$
\text { Quick Ratio }=\frac{2.851 .516 .716-607.795 .995}{13.846 .142 .221} \times 100 \%=16 \%
$$

Hasil perhitungan Quick Ratio pada tahun 2016 adalah sebesar 19\% yang dapat diartikan bahwa setiap Rp 1,- hutang lancar dijamin oleh Rp 1,9 aset lancar. Pada tahun 2017 Quick Ratio adalah sebesar 12\% yang dapat diartikan bahwa setiap Rp 1,- hutang lancar dijamin oleh Rp 1,2 aset lancar. Pada tahun 2018 Quick Ratio adalah sebesar 16\% yang dapat diartikan bahwa setiap Rp 1,- hutang lancar dijamin oleh Rp 1,6 aset lancar. Sehingga dapat disimpulkan bahwa Quick Rasio Palace Hotel dalam keadaan masih likuid. Karena masih dapat menutupi hutang lancar oleh aset lancarnya.

\section{Cash Ratio}

Cash Ratio Palace Hotel Tahun 2016 :

$$
\text { Cash Ratio }=\frac{583.122 .092}{7.384 .000 .000} \times 100 \%=8 \%
$$

Cash Ratio Palace Hotel Tahun 2017 : 


$$
\text { Cash Ratio }=\frac{705.239 .318}{10.818 .487 .955} \times 100 \%=7 \%
$$

Cash Ratio Palace Hotel Tahun 2018 :

$$
\text { Cash Ratio }=\frac{1.266 .518 .057}{13.846 .142 .221} \times 100 \%=9 \%
$$

Hasil perhitungan Cash Ratio Palace tahun 2016 adalah $8 \%$ atau 0.08 kali yang berarti bahwa perusahaan memiliki kemampuan membayar utang lancar yang cukup rendah dikarenakan perbandingan kas dan setara kas dengan hutang lancar yang rendah. Pada tahun 2017 Cash Ratio adalah 7\% atau 0.07 kali, hal ini tidak jauh berbeda dengan tahun sebelumnya bahkan mengalami penurunan. Dan pada tahun 2018 Cash Ratio adalah 9\% atau 0.09 kali, sehingga pada tahun ini Cash Rasio mengalami kenaikan walaupun terbilang masih rendah. Sehingga dapat disimpulkan bahwa Cash Rasio Palace Hotel dalam 3 tahun tersebut sangat rendah

\section{Rasio Solvabilitas}

\section{Total Debt to Total Asset (DAR)}

Total Debt to Total Asset Palace Hotel pada tahun 2016 :

$$
\mathrm{DAR}=\frac{45.941 .150 .000}{43.401 .961 .444} \times 100 \%
$$

Total Debt to Total Asset Palace Hotel pada tahun 2017 :

$$
D A R=\frac{43980829643}{36.714 .292 .554} \times 100 \%=11,97 \%
$$

Total Debt to Total Asset Palace Hotel pada tahun 2018 :

$$
D A R=\frac{42.154 .954 .415}{31.350 .143 .527} \times 100 \%=13,44 \%
$$

Berdasarkan analisis tersebut, dapat disimpulkan bahwa Total Debt to Total Asset pada tahun 2016-2018 Palace Hotel berturut turut adalah 10,58\%, 11,97\%, dan $13,44 \%$ yang berarti bahwa sebanyak $10,58 \%, 11,97 \%$, dan $13,44 \%$ aset pada 3 tahun tersebut dibiayai oleh utang. Semakin tinggi nilai DAR, maka perusahaan semakin berisiko ketika mengalami likuiditas. 
Analisis Total Debt to Total Asset menunjukkan angka rasio yang besar dimiliki oleh Palace Hotel pada tiga tahun tersebut. Hal itu berarti Palace Hotel menggunakan persentase utang yang hampir sama besarnya dengan persentase total aktiva. Berdasarkan sudut pandang pemegang saham, hal ini dianggap buruk, tetapi apabila dilihat dari sisi pemilik usaha hal ini bisa jadi menguntungkan dalam hal melipatgandakan laba.

\section{Total Debt to Total Equity (DER)}

Total Debt to Total Equity Palace Hotel pada tahun 2016 :

$$
D E R=\frac{45941150000}{-9.923 .188 .558} \times 100 \%=-46,29 \%
$$

Total Debt to Total Equity Palace Hotel pada tahun 2017 :

$$
D E R=\frac{43.980 .829 .643}{-18.085 .025 .044} \times 100 \%=-24,31 \%
$$

Total Debt to Total Equity Palace Hotel pada tahun 2018 :

$$
D E R=\frac{42.154 .954 .415}{-24.650 .953 .111} \times 100 \%=-17,10 \%
$$

Berdasarkan analisis tersebut, dapat disimpulkan bahwa Total Debt to TotalEquity pada tahun 2016-2018 Palace Hotel berturut turut adalah -46,29\%, -24,31\%, dan $13,44 \%$ yang berarti bahwa sebanyak $-46,29 \%,-24,31 \%$, dan $-13,44 \%$ modal dibiayai oleh utang. Dalam hal ini, batas wajar DER perusahaan adalah 80-110\% atau 0,8-1,1 kali. Semakin tinggi nilai DER, maka perusahaan semakin berisiko ketika mengalami likuiditas, begitupun sebaliknya apabila nilai DER terlalu rendah.

\section{Rasio Aktivitas}

\section{Inventory Turnover Rasio}

Inventory Turnover Ratio Palace Hotel Tahun 2016 :

$$
I T R=\frac{25.753 .889 .113}{1.092 .006 .117}=23,58 \mathrm{kali}
$$


Inventory Turnover Ratio Palace Hotel Tahun 2017 :

$$
I T R=\frac{22.278 .027 .495}{539.369 .845}=41,30 \mathrm{kali}
$$

Inventory Turnover Ratio Palace Hotel Tahun 2018 :

$$
I T R=\frac{20.671 .581 .898}{607.795 .995}=34,01 \mathrm{kali}
$$

Artinya hotel memiliki perputaran persediaan rata-rata atau persediaan rata-rata terjual 23,58 kali pada tahun 2016, jika dibagi dengan jumlah hari dalam satu tahun maka akan diperoleh rata-rata hari yang dibutuhkan untuk produk terjual yaitu 365 / 23,58 = 15, 47 hari. Rata-rata perputaran persediaan atau persediaan terjual yang tinggi yaitu 41,30 kali pada tahun 2017 dan mengalami kenaikan dari tahun 2016 sebesar 41,30 - 23, $58 / 23,58=0,75$ atau $75 \%$, jika dibagi dengan jumlah hari dalam satu tahun maka akan diperoleh rata-rata hari yang dibutuhkan untuk produk terjual yaitu $365 / 41,30=8,83$ hari. Rata-rata perputaran persediaan atau persediaan terjual rata rata 34,01 kali pada tahun 2018, dan mengalami penurunan dari tahun 2017 sebesar 34,01 - 41,30 / 41,30 =-0, 17 atau 17\%, jika dibagi dengan jumlah hari dalam satu tahun maka akan diperoleh rata-rata hari yang dibutuhkan untuk produk terjual yaitu 365 / 34,01 = 10,73 hari.

Untuk menilai apakah angka dari rasio perputaran persediaan di atas bagus atau tidak sebenarnya relatif karena tidak ada standar yang tetap untuk itu, hanya setelah dibandingkan dengan rasio dari perusahaan atau industri sejenis dan dari periode sebelumnya diperolehlah rasio perputaran persediaan yang lebih tinggi (hari sampai barang terjual lebih kecil atau lebih cepat terjual) maka itulah yang terbaik

\section{Fixed Asset Turnover Ratio}

Fixed Assets Turnover Ratio Palace Hotel Tahun 2016 :

$$
F A T R=\frac{25.753 .889 .113}{36.221 .644 .992}=0,71 \mathrm{kali}
$$

Fixed Assets Turnover Ratio Palace Hotel Tahun 2017 : 
ARTIKEL

$$
F A T R=\frac{22.278 .027 .495}{30.556 .042 .868}=0,72 \mathrm{kali}
$$

Fixed Assets Turnover Ratio Palace Hotel Tahun 2018 :

$$
F A T R=\frac{20.671 .581 .898}{24.461 .796 .430}=0,84 \mathrm{kali}
$$

Hasil perhitungan Fixed Assets Turnover Ratio pada tahun 2016 produktivitas dari aset tetap untuk menghasilkan pendapatan adalah 0,71 kali, angka ini sangat kecil sekali untuk fixed asset turnover ratio. Pada tahun 2017, hanya mengalami kenaikan sebesar 0,01 dari tahun 2016 yaitu menghasilkan pendapatan 0,72 kali. Dan produktivitas dari aset tetap untuk menghasilkan pendapatan adalah 0,84 kali pada tahun 2018, mengalami kenaikan sebesar 0,12 dari tahun 2017

Hasil dari penghitungan rasio perputaran aset tetap di atas menunjukkan angka yang relativ rendah, artinya ada sesuatu yang harus diubah oleh manajemen hotel agar rasio perputaran aset tetap ini bisa meningkat dan menunjukkan angka yang relatif tinggi, pemasaran dari hotel harus lebih meningkatkan dan mengembangkan produk atau layanan hotel, agar lebih bisa menarik para pengunjung hotel

\section{Total Assets Turnover (TATO)}

Total Assets Turnover Palace Hotel pada tahun 2016 :

$$
\text { TATO }=\frac{25.753 .889 .113}{36.221 .644 .992} \times 100 \%=71,1 \%
$$

Total Assets Turnover Palace Hotel pada tahun 2017 :

$$
\text { TATO }=\frac{22.278 .027 .495}{30.556 .042 .868} \times 100 \%=72,9 \%
$$

Total Assets Turnover Palace Hotel pada tahun 2018 :

$$
\text { TATO }=\frac{20.671 .581 .898}{24.461 .796 .430} \times 100 \%=84,5 \%
$$

Nilai rasio dari Total Assets Turnover Palace Hotel 3 dari tahu 2016 hingga tahun 2018 angkanya melebihi 50\% yang artinya penjualan atau pendapatan yang dihasilkan oleh Palace Hotel dari total aset yang dimiliki lebih dari separuh total asetnya. Semakin tinggi nilai Total Assets Turnover ini maka semakin baik dan 
artinya Palace Hotel telah memaksimalkan aset yang dimiliki untuk menghasilkan penjualan yang lebih tinggi dan mampu menaikkan Total Assets Turnover hingga tahun 2018. Artinya mendapati kenaikan setiap tahunya.

\section{Average Collection Period (ACP)}

Average Collection Period Palace Hotel pada tahun 2016 :

$$
A C P=\frac{\left.\left(\frac{(368.006 .929+422.172 .049+350.233 .212)}{3}\right) \times 365\right)}{25.753 .889 .113}=2.69 \text { hari }
$$

Average Collection Period Palace Hotel pada tahun 2017 :

$$
A C P=\frac{\left.\left(\frac{(368.006 .929+422.172 .049+350.233 .212)}{3}\right) \times 365\right)}{22.278 .027 .495}=6.22 \text { hari }
$$

Average Collection Period Palace Hotel pada tahun 2018 :

$$
A C P=\frac{\left.\left(\frac{(368.006 .929+422.172 .049+350.233 .212)}{3}\right) \times 365\right)}{20.671 .581 .898}=6,71 \text { Hari }
$$

Rata-rata piutang berputar pada tahun 2016 yaitu 2,69 Hari atau dalam 3 hari. Berarti pihak Palace Hotel secara rata-rata mengumpulkan piutangnya dalam jangka waktu 3 hari pada tahun 2016. Rata-rata piutang berputar pada tahun 2017 yaitu 6,22 Hari atau dalam 7 hari. Berarti pihak Palace Hotel secara rata-rata mengumpulkan piutangnya dalam jangka waktu 7 hari pada tahun 2017. Rata-rata piutang berputar pada tahun 2018 yaitu 6,71 Hari atau dalam 7 hari. Berarti pihak Palace Hotel secara rata-rata mengumpulkan piutangnya dalam jangka waktu 7 hari pada tahun 2018 .

Dari Average Collection Period atau perputaran piutang harian Palace Hotel dalam 3 tahun ini mengalami penurunan kemampuan pihak hotel. Rata-rata perputaranya yang di tahun 2016 hanya dalam waktu 3 hari, kemudian pada tahun 2017 dan 2017 menjadi 7 hari.

\section{Receivable Turnover}

Receivable turnover Palace Hotel pada tahun 2016 :

$$
\text { RTO }=\frac{25.753 .889 .113}{380.137 .396}=67,75 \mathrm{kali}
$$


Receivable turnover Palace Hotel pada tahun 2017 :

$$
\mathrm{RTO}=\frac{22.278 .027 .495}{380.137 .396}=58,60 \mathrm{kali}
$$

Receivable turnover Palace Hotel pada tahun 2018 :

$$
\mathrm{RTO}=\frac{20.671 .581 .898}{380.137 .396}=54,38 \mathrm{kali}
$$

Hasil perhitungan $R T O$ dari tahun 2016 sampai tahun 2018 menunjukkan adanya penurunan dari tahun ke tahun, yaitu pada tahun 2016 sebesar 67,75 kali, tahun 2017 sebesar 58,60 kali, dan tahun 2018 sebesar 54,38 kali. Ini berarti adanya over investment dalam piutang yang berarti perusahaan tidak mampu melakukan penagihan piutang kepada pelanggan sehingga dapat menimbulkan risiko piutang yang tak tertagih, juga bisa karena bagian kredit atau penagihan bekerja tidak efektif dan mungkin karena adanya perubahan kebijaksanaan dalam pemberian kredit.

\section{Working Capital Turnover (Perputaran Modal Kerja)}

Working capital turnover Palace Hotel pada tahun 2016 :

$$
\text { WCTO }=\frac{25.753 .889 .113}{-4.861 .564 .756}=-5,29 \mathrm{kali}
$$

Working capital turnover Palace Hotel pada tahun 2017 :

$$
\text { WCTO }=\frac{22.278 .027 .495}{-9.007 .594 .064}=-2,47 \mathrm{kali}
$$

Working capital turnover Palace Hotel pada tahun 2018 :

$$
\text { WCTO }=\frac{20.671 .581 .898}{-10.994 .625 .506}=-1,88 \mathrm{kali}
$$

Hasil perhitungan WCTO dari tahun 2016 sampai tahun 2018 mengalami peningkatan dari tahun ke tahun, yaitu pada tahun 2016 sebesar -5,29 kali, tahun 2017 sebesar -2,47 kali dan tahun 2018 sebesar -1,88 kali. Ini terjadi karena penjualan meningkat atau modal kerja yang menurun, artinya perusahaan dapat memaksimalkan modal kerja untuk menghasilkan penjualan yang lebih tinggi. Tingkat perputaran modal kerja yang meningkat mengindikasikan perusahaan telah mengelola modal kerjanya secara baik dan efisien. 


\section{G. KESIMPULAN}

Berdasarkan hasil penelitian yang dilakukan dengan menganalisis kinerja pencatatan keuangan yang dilakukan oleh pihak Palace Hotel hasil yang didapatkan melalui rasio profitabilitas, likuiditas, solvabilitas dan aktivitas maka peneliti menarik kesimpulan sebagai berikut:

1. Berdasarkan hasil analisis menggunakan rasio profitabilitas Palace Hotel belum bisa mencapai tingkat keuntungan yang baik. Dilihat dari hasil analisis ROE, ROA dan NPM yang terbilang masih banyak nilai negatif dengan kondisi yang tidak stabil, terkadang naik dan turun setiap tahunnya. Kemampuan perusahaan untuk memaksimalkan laba ini dinilai kurang karena sering kali terjadi penurunan nilai asset, yang menyebabkan peningkatan laba bersih yang kurang menjadi sangat terlihat.

2. Berdasarkan hasil analisis menggunakan rasio likuiditas Palace Hotel terbilang cukup likuid karena masih memiliki aset lancar yang dapat dijadikan jaminan atas hutang lancarnya. Namun hutang usaha juga masih terbilang sangat tinggi dan sering kali mengalami turun naik. Cash ratio yang dimiliki Palace Hotel dalam 3 tahun terakhir ini cukup rendah, walaupun masih memiliki cukup aset yang bisa dijadikan jaminan, namun kemampuannya dalam membayar hutang lancar yang rendah bisa jadi membahayakan perusahaan.

3. Berdasarkan hasil analisis menggunakan rasio solvabilitas Palace Hotel memiliki tingkat risiko yang tinggi apabila mengalami likuiditas. Persentase utang yang hampir sama besarnya dengan persentase total aktiva yang membuat sudut pandang bahwa Palace Hotel menggunakan biaya dengan utang. Namun bagi pemilik usaha ini bisa menguntungkan dalam menambah tingkat laba.

4. Berdasarkan hasil analisis menggunakan rasio aktivitas Palace Hotel dalam menggunakan asetnya belum cukup efisien, namun modal kerja yang dimiliki bisa dikelola dengan baik dan efisien. Meskipun adanya penurunan kemampuan pihak hotel dalam soal piutang, yang 3 tahun belakangan ini mengalami penurunan, palace hotel tetap mampu memanfaatkan celah lain untuk menambah pendapatanya melalui peningkatan fasilitas atau promosi lainya. Sehingga dapat menambah total aset perusahaan setiap tahunya yang pendapatan pertahunya melebih dari separuh total asset yang dimiliki.

Dapat diambil garis besarnya dari hasil analisis berdasarkan analisis rasio 
keuangan yang dilakukan. Palace Hotel dikatakan belum cukup stabil dalam proses perputarannya, yang sering kali mengalami penurunan dan peningkatan yang berbeda di setiap tahunya. Namun demikian, Palace Hotel mencatatkan kinerja

keuangan yang saling menutupi kekurangan. Yang membuat Palace Hotel tetap berjalan dengan baik meskipun tidak memiliki modal yang cukup sehingga harus berhutang untuk menutupi modalnya.

\section{DAFTAR PUSTAKA}

Barus, M., Sudjana, N., \& Sulasmiyati, S. (2017). Penggunaan Rasio Keuangan Untuk Mengukur Kinerja Keuangan.

PERUSAHAAN (Studi pada PT. Astra Otoparts, Tbk dan PT. Goodyer Indonesia, Tbk yang Go Public di Bursa Efek Indonesia). Jurnal Administrasi Bisnis S1 Universitas Brawijaya, 44(1), 154-163.

Rialdy, N., Muhammadiyah, U., \& Utara, S. (2018). Analisis Laporan Keuangan Dengan Metode Trend Sebagai Dasar Menilai Analysis of the Financial Report with Trend Method as a basis for assessing the financial condition in Pilgrimag Analisis Laporan Keuangan Dengan Metode Trend Sebagai Dasar Menilai Ko. February.

Cahyaningtyas. 2008. Penggunaan Analisis Ratio Finansial Untuk Mengetahui Prestasi Manajer Keuangan Dalam Mengelola Perusahaan (Perusahaan semen yang listing di BEJ). Skripsi. Fakultas Ekonomi. Universitas Merdeka Malang.

Hariadi, Indra. 2013. Penilaian Kinerja Keuangan Perusahaan Berdasarkan Analisis Rasio Keuangan Dan Economic Value Added (EVA). Skripsi. Fakultas Ilmu Administrasi. Universitas Brawijaya Malang.

Masyhuri dan Zainuddin, M. 2008. Metodologi Penelitian. PT. Refika Aditama. Bandung.

Masyhuri dan Zainuddin,M. 2008. Metodologi Penelitian: Pendekatan Praktis dan Aplikasi. Bandung: Refika Aditama.

Moleong, Lexy J. 2007. Metodologi Penelitian Kualitatif, Penerbit PT Remaja Rosdakarya Offset, Bandung. 